\title{
RADIOCARBON DATING, MINERALOGY, AND ISOTOPIC COMPOSITION OF HACKBERRY ENDOCARPS FROM THE NEOLITHIC SITE OF AŞIKLI HÖYÜK, CENTRAL TURKEY
}

\author{
${ }^{1}$ Department of Geosciences, University of Arizona, Tucson, AZ 85721, USA. \\ ${ }^{2}$ Department of Geology and Environmental Earth Science, Miami University, Oxford, OH 45056, USA. \\ ${ }^{3}$ Department of Anthropology, University of Arizona, Tucson, AZ 85721, USA. \\ ${ }^{4}$ Institute for Archaeological Sciences, Eberhard Karls University Tübingen, 72070 Tübingen, Germany. \\ ${ }^{5}$ Department of Prehistory, Istanbul University, Istanbul, Turkey. \\ *Corresponding author: quadej@email.arizona.edu.
}

JAY QUADE ${ }^{1 *}$, SHANYING LI ${ }^{2}$, MARY C. STINER ${ }^{3}$, AMY E. CLARK ${ }^{1,3}$, SUSAN M. MENTZER ${ }^{4}$, and MIHRIBAN ÖZBASARAN ${ }^{5}$

\begin{abstract}
Carbonate is abundant in many Neolithic tells and is a potentially useful archive for dating and climate reconstruction. In this paper, we focus on the mineralogy, radiocarbon dating, and stable isotope systematics of carbonate in hackberry endocarps. Hackberry fruits and seeds are edible in fresh and stored forms, and they were consumed in large quantities in many Neolithic sites in the Near East, including the site of our study, Aşıklı Höyük in central Anatolia, an Aceramic Neolithic tell occupied from about 9.4 to $>10.3 \mathrm{BP}(7.4$ to $>8.3 \mathrm{BCE})$. Detailed ${ }^{14} \mathrm{C}$ age control provided by archaeological charcoal permits a test of the fidelity in ${ }^{14} \mathrm{C}$ dating of hackberry endocarps. Modern endocarps and leaves yield fraction modern ${ }^{14} \mathrm{C}$ values of $1.050-1.066$, consistent with levels present in the atmosphere when sampled in 2009 . On the other hand, archaeological endocarps yield consistently younger ages than associated charcoal by ca. $130{ }^{14} \mathrm{C}$ years (ca. 220 calendar years) for samples about 10,000 years old. We speculate this is caused by the slight addition of calcite or recrystallization to calcite in the endocarp, as detected by scanning electron microscopy. Subtle addition or replacement of calcite by primary aragonite is not widely recognized in the ${ }^{14} \mathrm{C}$ community, even though similar effects are reported from other natural carbonates such as shell carbonate. This small (but consistent) level of contamination supports the usefulness of endocarps in dating where other materials like charcoal are lacking. Before dating, however, hackberries should be carefully screened for mineralogical preservation and context. We examined the carbon and oxygen isotopic systematics of the fossil endocarps to try to establish potential source areas for harvesting. Most of the hackberries are enriched in ${ }^{18} \mathrm{O}$ compared to local water sources, indicating that they were drawing on highly evaporated soil water, rather than the local (perched and regional) water table sampled in our study. Isotopic evidence therefore suggests that most but not all of the hackberries were harvested from nearby mesas well above the local streams and seeps fed by the water table.
\end{abstract}

Keywords: radiocarbon, geoarchaeology, micromorphology, stable isotopes, microcontextual approach.

\section{INTRODUCTION}

Hackberries in Turkey are the annual fruits of Celtis tournefortii and the mineralized endocarps of the fruits are mostly carbonate $\left(\mathrm{CaCO}_{3}\right)$. Because of their mineral content, hackberry endocarps are preserved abundantly in the Neolithic archaeological sites of Anatolia and the Levant, including Çatalhöyük (Shillito et al. 2009). Prior work developing the potential of hackberries and other calcareous seed endocarps for paleoenvironmental reconstruction (e.g. Wang et al. 1997; Jahren et al. 2001; Pustovoytov et al. 2010) motivated us to examine the utility of hackberry endocarps for ${ }^{14} \mathrm{C}$ dating and paleoenvironmental reconstruction at Aşıklı Höyük.

At 4 hectares in total area, Asıklı Höyük is the earliest large village in central Anatolia (Esin et al. 1991, 1999). The site is a tell standing ca. $14 \mathrm{~m}$ above the nearby Melendiz Creek (Figure 1), a perennial system nourished by run-off and groundwater from the nearby high peaks (>3000 m) of Hasan Dağ and the Melendiz
Mountains. In more than 15 years of excavations at Asıklı Höyük, archaeologists have uncovered four main occupation levels spanning over $10 \mathrm{~m}$ of anthropogenic deposits. The deepest portions of the site are exposed (Figure 2) in the "Deep Sounding" located on the northern edge of the mound. At the base of the mound, Level 4 is characterized archaeologically by round and semi-round mudbrick structures and open-air activity areas. The overlying Level 3 contains multiple construction phases and is notable for a shift in the shape of buildings from round to rectangular, as well as the development of a large, deep midden, which we sampled in this study. In addition to its architectural features, Asıklı Höyük is notable for faunal evidence for "protodomestication" of sheep and goats (Buitenhuis 1997; Stiner et al. 2014). Previous ${ }^{14} \mathrm{C}$ dating of mainly Levels 2 and 3 at Asıklı Höyük yielded dates that span roughly 8300-7400 BCE (10,300-9400 BP). Özbaşaran and Buitenhius (2002) have designated this interval as ECA (Early Central Anatolian) Phase II, roughly coeval with the pre-Pottery Neolithic A in the Levant. This study expands on the dating of Level 3 using charcoal and hackberries. 


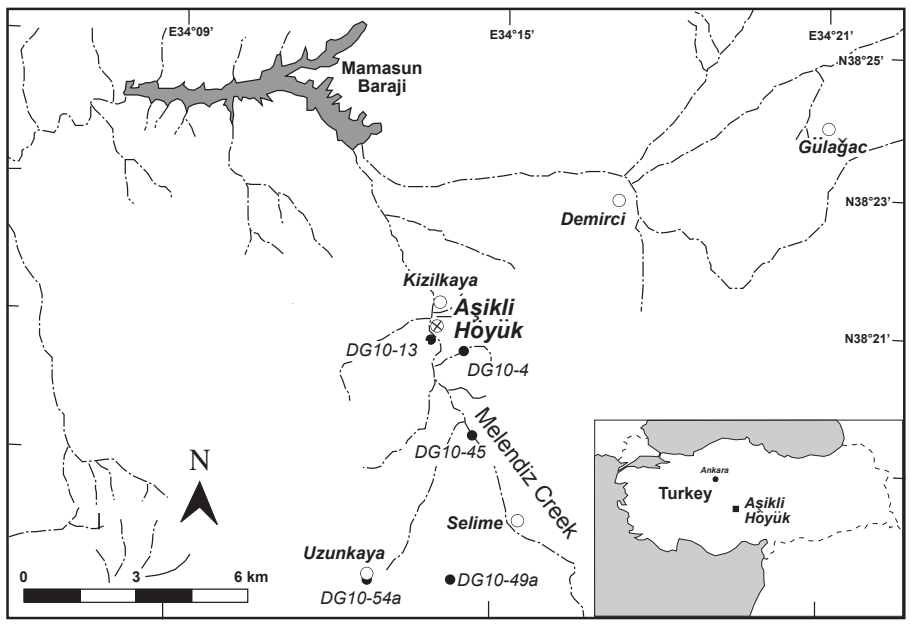

Figure 1. Location of the Neolithic site at Asıkl Höyük along Melendiz Creek in central Anatolia. Filled circles with sample numbers indicate locations of selected water samples in the immediate vicinity of the site (Table 2). Open circles are modern villages in the area.

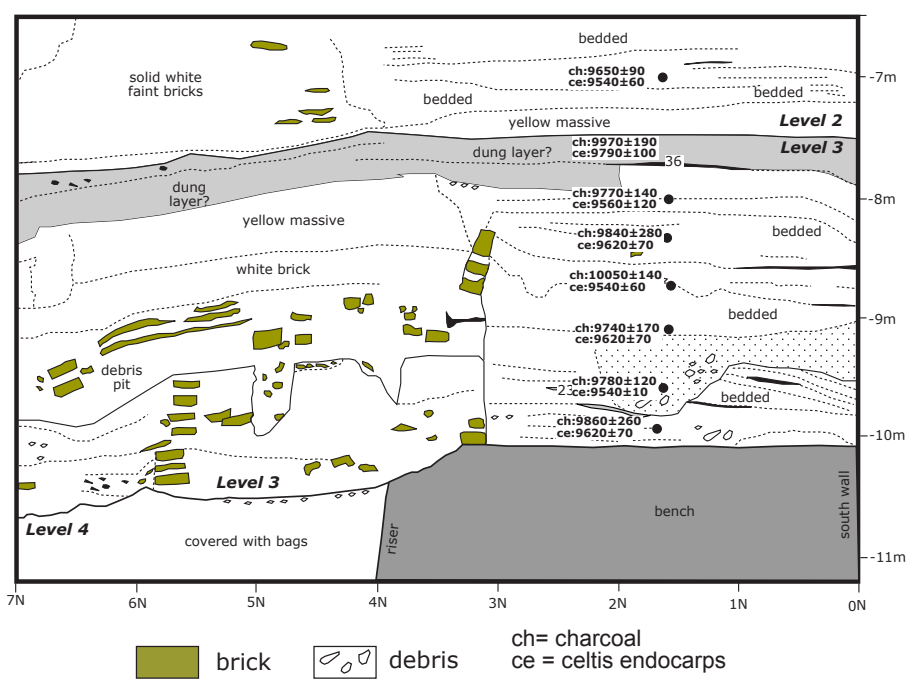

Figure 2. Stratigraphic locations of the paired samples from the "Deep Sounding"/ Trench 4GH used for comparison of ages from co-occurring charcoal (ch) and Celtis endocarps (ce). Dated samples in calendar years (Table 1) are in bold letters. Samples 56 and 57 (Table 1) were collected from the south wall (not shown here) of Trench $4 \mathrm{GH}$.

Our main focus in this paper is on dating by ${ }^{14} \mathrm{C}$ and stable isotopic analysis of hackberry endocarps. Further information about the context of the archaeological hackberries is provided by micromorphology, supplemented with micro-Fourier transform infrared analyses ( $\mu$-FTIR). This "microcontextual" approach (sensu Matthews 2005; Goldberg and Berna 2010) pairs different types of high-resolution analyses in order to understand impacts of site formation processes and sedimentary microenvironment on the preservation and context of sampled archaeological materials. A similar approach has been applied successfully in a Near Eastern tell setting to provide context for ${ }^{14} \mathrm{C}$ dating samples (Toffolo et al. 2012).
Hackberry fruits and seeds were consumed in large quantities at Asıklı Höyük. Macroscale observations and micromorphological analyses of sediment blocks indicate that hackberry endocarps are most abundant in the middens and open-air activity areas of Levels 4 and 3. The hackberry endocarps are present both as lenses and as isolated finds within more generalized refuse layers, the focus of sampling for this study. They are also found within the sediment overlying floor layers inside residential structures, and within mortar samples from Level 4.

Modern hackberries are spherical, 5-10 $\mathrm{mm}$ in diameter, and consist of three layers: an inner endosperm made of partially mineralized organic spheres, the well-mineralized endocarp with a honeycomb structure of fibrous carbonate and scalloped surface, and an outer fleshy mesocarp (Figure 3). All previous studies identify aragonite and minor silica as the only mineralizing phases (Cowan et al. 1997; Wang et al. 1997; Jahren et al. 2001) (but see Results section).

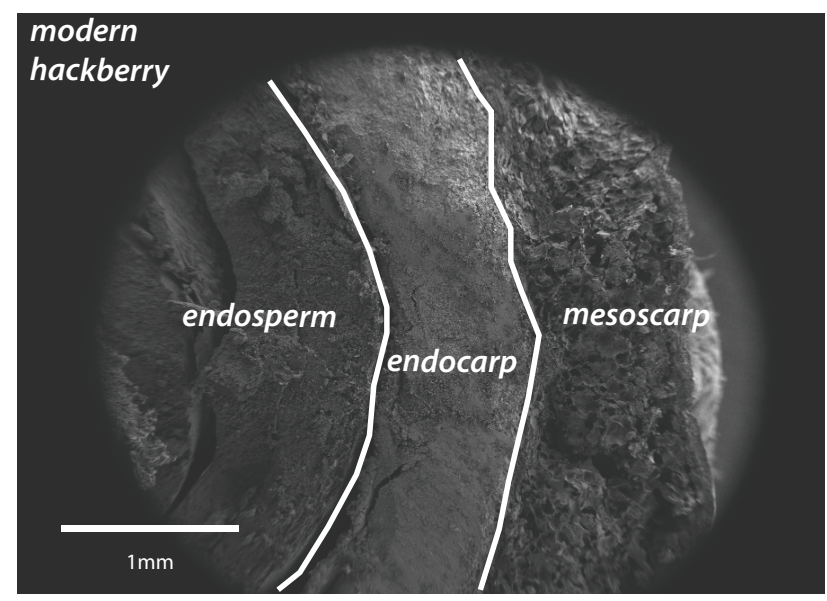

Figure 3. Scanning electron microscope image of the three distinct layers of a modern hackberry seed: (1) inner fruit or endosperm composed of partially mineralized spherical organic bodies, (2) endocarp consisting principally of aragonite and calcite, and (3) outer fruit or mesocarp with a framework of organic matter and some calcite crystals.

Modern hackberry shrubs are living throughout the area today, in two main settings. The first is along Melendiz Creek and its small tributaries incised into the local volcanic bedrock. The second is where shrubs grow on the dry volcanic mesas overlooking the Melendiz Creek drainage network. We sampled both modern hackberries and local water sources in the area to provide a context for interpreting the stable isotope results from archaeological hackberries in refuse layers at the site.

\section{METHODS}

Both modern and archaeological fruits were imaged using Zeiss Supra 35 scanning electron microscopy (SEM) at Miami University (Ohio). The SEM imaging was performed on uncoated, freshly broken surfaces of fruits. The imaging was conducted at an accelerating voltage of $2 \mathrm{keV}$ with $7.0-8.5 \mathrm{~mm}$ working distance. 
The mineralogy of modern and fossil endocarps was first evaluated using X-ray diffraction spectrometry (XRD) also at Miami University (Ohio). Endocarps were cleaned with distilled water and dried in room temperature. Samples were gently powered by hand using a mortar and pestle. XRD data were collected on a Sintag powder diffractometer, using $\mathrm{CuK} \alpha$ radiation with an acceleration voltage of $40 \mathrm{keV}$ and a tube current of $35 \mathrm{~mA}$. Carbonate mineralogy was determined from mineral X-ray peaks (Tucker 1995).

Further mineralogical analysis by $\mu$-FTIR analyses were conducted on hackberry endocarps visible in thin section using a FTIR microscope equipped with a germanium crystal attenuated total reflectance objective (Agilent Technologies). Infrared absorbance spectra were collected at resolutions of $4 \mathrm{~cm}^{-1}$ and compared to spectra produced from calcite, aragonite, amorphous silica, and apatite references using the same techniques.

Oriented blocks of sediment were collected from exposed excavation profiles, impregnated with a mixture of polyester resin and styrene catalyzed with MEKP, and processed into petrographic thin sections. The thin sections were studied at a variety of magnifications (10-200×) using petrographic microscopes, and described using standard terminology (Stoops 2003).

At each modern water sample site, $15 \mathrm{~mm}$ of unfiltered water was sealed with Teflon and electrician's tape into a centrifuge tube and refrigerated in the laboratory. $\delta^{18} \mathrm{O}(\mathrm{SMOW})$ of water samples was measured using the $\mathrm{CO}_{2}$ equilibration method on an automated sample preparation device attached directly to a Finnigan Delta $\mathrm{S}$ mass spectrometer at the University of Arizona. The $\delta \mathrm{D}$ values of water were measured using an automated chromium reduction device (H-Device) attached to the same mass spectrometer. The values were corrected based on internal lab standards, which are calibrated to SMOW and SLAP. The analytical precision for $\delta^{18} \mathrm{O}$ and $\delta \mathrm{D}$ measurements is $0.08 \%$ and $0.6 \%$, respectively $(1 \sigma)$. Water isotopic results are reported using standard $\delta$-per mil notation relative to SMOW.

Carbonates analyzed for $\delta^{18} \mathrm{O}$ and $\delta^{13} \mathrm{C}$ values were heated at $250^{\circ} \mathrm{C}$ for 3 hours in vacuo before stable isotopic analysis using an automated sample preparation device (Kiel III) attached directly to a Finnigan MAT 252 mass spectrometer at the University of Arizona. Measured $\delta^{18} \mathrm{O}$ and $\delta^{13} \mathrm{C}$ values were corrected using internal laboratory standards calibrated to NBS-19. Precision of repeated standards is $\pm 0.11 \%$ for $\delta^{18} \mathrm{O}$ and 0.07 for $\delta^{13} \mathrm{C}(1 \sigma)$. Carbonate isotopic results are reported using standard $\delta$-per mil notation relative to VPDB.

Charcoal samples for ${ }^{14} \mathrm{C}$ analysis were pretreated using the conventional acid-base-acid protocol. Hackberry endocarps were pretreated in $2 \% \mathrm{H}_{2} \mathrm{O}_{2}$ to remove organic matter, soaked overnight in distilled water, and copiously $(>5 \times)$ rinsed in more distilled water before drying in an oven at $50^{\circ} \mathrm{C}$. Samples were converted to $\mathrm{CO}_{2}$, graphitized, and analyzed at the University of Arizona NSF accelerator facility. ${ }^{14} \mathrm{C}$ years were converted to calendar years using CALIB 6.01 (http://calib.qub.ac.uk/calib/), and resultant ages expressed as the median of the $2 \sigma(95 \%)$ calibrated age range.

\section{RESULTS AND DISCUSSION}

\section{FTIR and Micromorphologic Evidence}

Archaeological contexts at Aşılılı Höyük that contain hackberries include hearths, occupation debris within structures, middens or refuse, stabling layers, and construction materials. Our micromorphological and $\mu$-FTIR analyses of sediment samples collected from these contexts indicate that hackberry endocarps were variably impacted by postdepositional chemical alteration (Figure 4). Endocarps located in discrete refuse layers

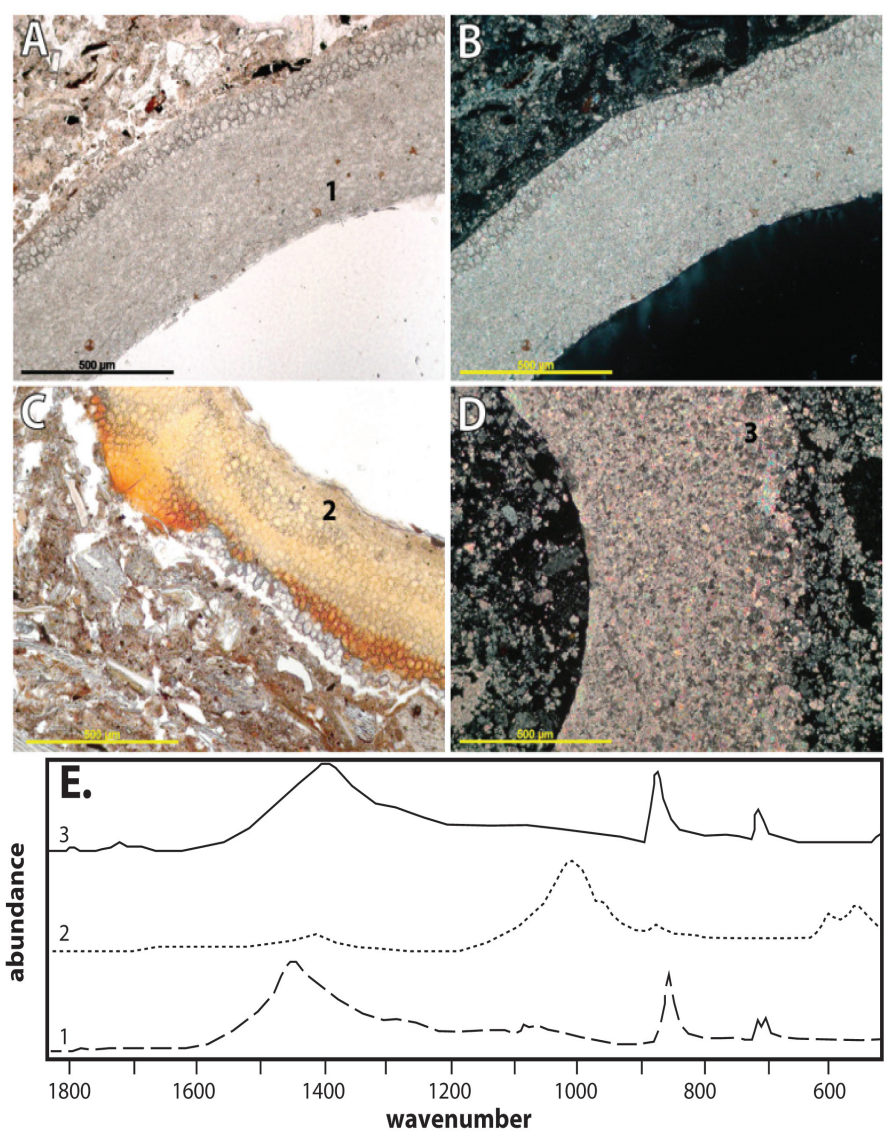

Figure 4. Microcontextual analysis of archaeological Celtis samples: (A) A Celtis endocarp in thin section. PPL. (B) Same view as (A), XPL. The outer edge of the endocarp is scalloped in morphology. (C) A phosphatized endocarp in a layer of dung is identified by its yellow to orange color in PPL (pictured here) and isotropy in XPL. Note that the morphologies of crystals within the endocarp are generally similar to those of the unaltered endocarp in (A) and (B). (D) A burned endocarp in a hearth exhibits similar interference colors in XPL as an unaltered endocarp, although the morphology of the crystals is lost. (E) $\mu$-FTIR measurements on the endocarps pictured above (locations indicated by numbers). The unaltered endocarp (1) exhibits absorbance peaks at 1445, 852, 711, and $668 \mathrm{~cm}^{-1}$, consistent with aragonite. The phosphatized endocarp (2) exhibits absorbance peaks at 1412, $1007,871,598$, and $555 \mathrm{~cm}^{-1}$, consistent with apatite mixed with minor amounts of calcite. The heated endocarp (3) exhibits absorbance peaks at 1392, 870, and $711 \mathrm{~cm}^{-1}$, consistent with calcite. A small shoulder at $668 \mathrm{~cm}^{-1}$ indicates that some aragonite is still present. 
within middens are typically well preserved, and have not been impacted by physical reworking. Likewise, endocarps present in construction materials, such as mortar, are also well preserved; however, the overall composition of mortar samples indicates that they were produced from recycled debris within the site. For these reasons, the samples in this study were preferentially selected from midden contexts.

Hackberry endocarps present in the occupation debris within structures and inside hearths are likely associated with primary processing and consumption activities. However, these contexts are not always ideal for dating samples due to mineralogical changes. Endocarps present inside hearths are composed of calcite (Figure 4e), likely as a result of conversion to calcium oxide during heating, followed by recarbonation upon cooling. Similarly, endocarps located in stabling layers exhibit secondary phosphatization with, in some cases, $100 \%$ replacement of the original aragonite by apatite (Figures 4c, e). Endocarps located in Level 4 activity spaces are likewise variably impacted by secondary phosphatization and recrystallization and are frequently physically reworked by human foot traffic, as evidenced by fragmentation and rounding.

\section{Carbon-14 Dating of Endocarps}

To contexturalize our archaeological samples, we dated a modern endocarp and leaf from hackberry shrubs living on a terrace carved into local volcanic bedrock about $1 \mathrm{~km}$ from the archaeological site. The leaf and endocarp of the living plant yielded post-bomb ages, with fraction modern carbon (FMC) at 1.050 and 1.066 (Table 1). Hackberries fruit yearly, and our results are consistent with the projected atmospheric FMC of $\sim 1.05$ (Levin et al. 2004) for our sampling year of 2009. This is also consistent with the findings of Wang et al. (1997), who documented ${ }^{14} \mathrm{C}$ equilibrium between endocarp carbonate and the atmospheric $\mathrm{CO}_{2}$ from numerous samples spanning AD 1889 to 1993.

From Aşıklı tell itself, we carefully sampled eight pairs of closely associated hackberry endocarps and charcoal, mostly from Level 3 (Figure 2). The host context of all samples is entirely midden or refuse layers, in which the endocarps are generally well preserved. The samples returned calibrated ages in the 9.5 to 10 kyr BP range, consistent with the general age constraints for Level 3 from other samples. Dating of co-occurring charcoal and endocarps in the Aşıklı deposits yields ${ }^{14} \mathrm{C}$ ages for the endocarps that are slightly but systematically younger by $130 \pm 90{ }^{14} \mathrm{C}$ years

Table 1. ${ }^{14} \mathrm{C}$ dates from paired Celtis endocarps and charcoal from Aşıklı Höyük.

\begin{tabular}{|c|c|c|c|c|c|c|}
\hline $\begin{array}{l}\text { Sample } \\
\text { AH'09- }\end{array}$ & $\begin{array}{l}\text { Lab code } \\
\text { AA- }^{1}\end{array}$ & Sample type ${ }^{2}$ & $\begin{array}{l}\text { Fraction } \\
\text { modern } \mathrm{C}\end{array}$ & ${ }^{14} \mathrm{C}$ yr BP & $\begin{array}{l}\text { cal yr BP } \\
(2 \sigma>95 \%)\end{array}$ & Stratigraphic level \\
\hline 56 & 87975 & fossil Celtis endocarp & 0.3407 & $8790 \pm 20$ & $9800 \pm 100$ & upper Level 4 refuse \\
\hline 57 & 87962 & charcoal & 0.3342 & $8830 \pm 40$ & $9930 \pm 230$ & upper Level 4 refuse \\
\hline 58 & 87980 & fossil Celtis endocarp & 0.3421 & $8770 \pm 20$ & $9790 \pm 100$ & upper Level 3 refuse/dung \\
\hline 59 & 87957 & charcoal & 0.3337 & $8850 \pm 30$ & $9970 \pm 190$ & upper Level 3 refuse/dung \\
\hline 60 & 87981 & fossil Celtis endocarp & 0.3509 & $8570 \pm 40$ & $9540 \pm 60$ & lower Level 2 refuse \\
\hline 61 & 87959 & charcoal & 0.3387 & $8720 \pm 20$ & $9650 \pm 90$ & lower Level 2 refuse \\
\hline 62 & 87982 & fossil Celtis endocarp & 0.3473 & $8640 \pm 30$ & $9560 \pm 120$ & upper Level 3 refuse \\
\hline 63 & 87958 & charcoal & 0.3372 & $8770 \pm 30$ & $9770 \pm 140$ & upper Level 3 refuse \\
\hline 64 & 87987 & fossil Celtis endocarp & 0.3464 & $8670 \pm 30$ & $9620 \pm 70$ & middle Level 3 refuse \\
\hline 65 & 87955 & charcoal & 0.3372 & $8770 \pm 40$ & $9840 \pm 280$ & middle Level 3 refuse \\
\hline 66 & 87983 & fossil Celtis endocarp & 0.3505 & $8560 \pm 40$ & $9540 \pm 60$ & middle Level 3 refuse \\
\hline 67 & 87961 & charcoal & 0.3308 & $8910 \pm 40$ & $10,050 \pm 140$ & middle Level 3 refuse \\
\hline 68 & 87985 & fossil Celtis endocarp & 0.3457 & $8690 \pm 20$ & $9620 \pm 70$ & basal Level 3 refuse \\
\hline 69 & 87979 & charcoal & 0.3373 & $8760 \pm 40$ & $9740 \pm 170$ & basal Level 3 refuse \\
\hline 70 & 87986 & fossil Celtis endocarp & 0.3499 & $8570 \pm 20$ & $9540 \pm 10$ & lower Level 3 refuse \\
\hline 71 & 87956 & charcoal & 0.3377 & $8760 \pm 20$ & $9780 \pm 120$ & lower Level 3 refuse \\
\hline 72 & 87976 & fossil Celtis endocarp & 0.3454 & $8690 \pm 20$ & $9620 \pm 70$ & basal Level 3 refuse \\
\hline \multirow[t]{3}{*}{73} & 87960 & charcoal & 0.3365 & $8780 \pm 40$ & $9860 \pm 260$ & basal Level 3 refuse \\
\hline & 87977 & modern (2009) Celtis leaf & 1.0504 & post-bomb & - & on ignimbrite next to Dig house \\
\hline & 87984 & modern (2009) Celtis endocarp & 1.0660 & post-bomb & - & on ignimbrite next to Dig house \\
\hline
\end{tabular}

1. AA- refers to Arizona Accelerator Facility number.

2. Listed as statigraphically paired charcoal and endocarps. 
(220 \pm 120 calendar years) than the closely paired charcoal (Table 1; Figure 5b).

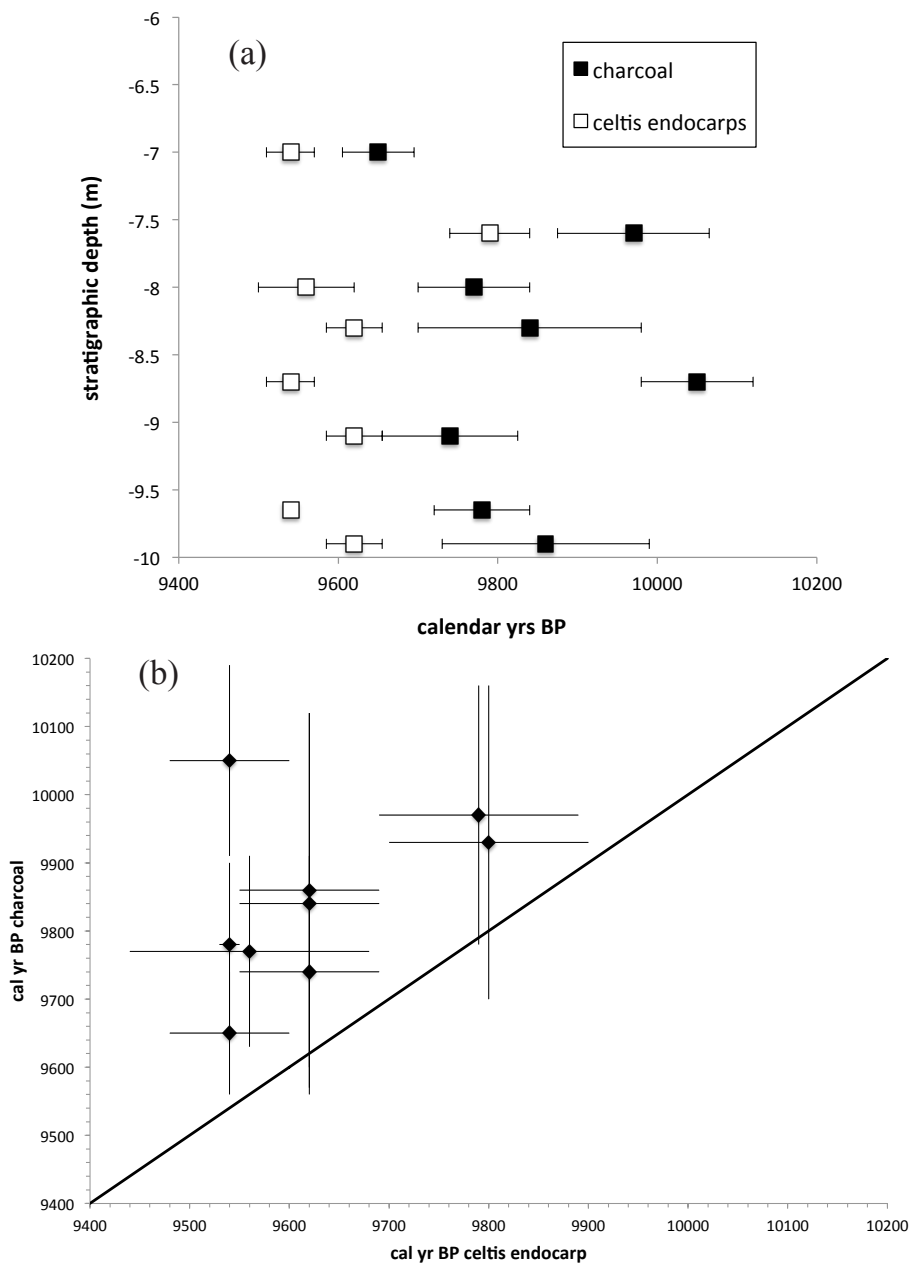

Figure 5. Calendar ages (in yr BP) of charcoal versus that of stratigraphically associated hackberry endocarps refuse layers, shown (a) by stratigraphic level and (b) by charcoal versus hackberry dates.

The archaeological samples come from finely bedded refuse layers, typically $1-2 \mathrm{~cm}$ in thickness. The Level 4 and 3 midden area contains hundreds to thousands of discrete lenses of dumped debris sourcing from a variety of contexts. Lenses of hackberry endocarps contain hundreds of individual berries and likely source from food preparation activities that occurred elsewhere in the site. Paired charcoal samples from layers located immediately above or below derive from hearth rake-out. In micromorphology samples, the high-porosity, random orientation of coarse inclusions and flat contacts between lenses of refuse indicate that they were not significantly disturbed by human foot traffic or bioturbation following deposition. Although evidence for postdepositional disturbance is not present, human decisions regarding waste disposal within the site, such as secondary deposition of old waste, may have resulted in superposition of older and younger materials within the midden. Our results show stratigraphic inversion of both the charcoal and hackberry dates (Figures 2, 5a). Unpublished dates from elsewhere in the site also can show such inversions, suggesting that the refuse layers represent a mixture of primary and recycled refuse, perhaps from ongoing excavation by Aşıklıans during house and other construction.

\section{Causes of the ${ }^{14} \mathrm{C}$ Deficiency in Endocarps}

One explanation we considered for the offset in ages between charcoal and endocarps is that the wood burned at the site could have been harvested from the older parts of trees. This could explain some but not all of the data, because some of the charcoal is burnt twigs, not ringwood. This mix of twigs and ringwood should not produce the consistently young ages of the endocarps compared coexisting charcoal. Pending testing with a larger data set, we tentatively reject this explanation.

Alternatively, the fossil endocarps have been altered mineralogically or by isotopic exchange, in the process adding a small amount of ${ }^{14} \mathrm{C}$ to samples. We investigated this possibility by examining the mineralogy, petrography, and surface morphology of modern and fossil endocarps. In hand specimens and petrographically, there is little evidence of alteration. Fossil endocarps retain a characteristic scalloped outer surface, although somewhat chalkier in appearance than modern endocarps. In thin section, the archaeological endocarps retained their high-order interference colors in cross-polarized light, and dense 10-30 $\mu \mathrm{m}$ crystals of aragonite characteristic of modern endocarps.

A closer study of the samples by SEM and XRD reveals subtle but clear evidence of addition calcite to samples. The archaeological samples (AH-62 and AH10-47) retained the characteristic endosperm and endocarp but had lost the outer fleshy mesocarp layer. Examination by SEM revealed two major differences between modern and archaeological endocarps: (1) secondary calcite crystals ca. 4-6 mm across are clearly present in archaeological hackberry endocarps, which suggest localized neomorphism of aragonite to calcite (Figure 6); and (2) rounded calcite aggregates in "honey-comb" cells of archaeological hackberry endocarps are more solid and are well lithified (Figure 6). By contrast, calcite aggregates in modern hackberry endocarp display empty holes (Figure 6). Infilling of the holes apparently occurs after burial, perhaps by dissolution of aragonite and precipitation of calcite infilling of holes in the primary aragonite.

Furthermore, XRD and SEM analyses of the modern hackberry endocarp, obtained from a living shrub, demonstrate the unexpected presence of calcite. Previous studies of modern hackberry endocarps all state that the only carbonate phase present is aragonite. Our sampled modern endocarp contains euhedral to subhedral bladed calcite (Figure 6); XRD analysis further confirms the presence of both aragonite and calcite in the modern endocarp (Figure 7b), similar to XRD results from archaeological endocarps (Figure 7a). At this point, we do not know if the presence of some primary calcite in the modern endocarp is a peculiarity of Celtis tournefortii or alternatively is present but undetected in other species of Celtis. 

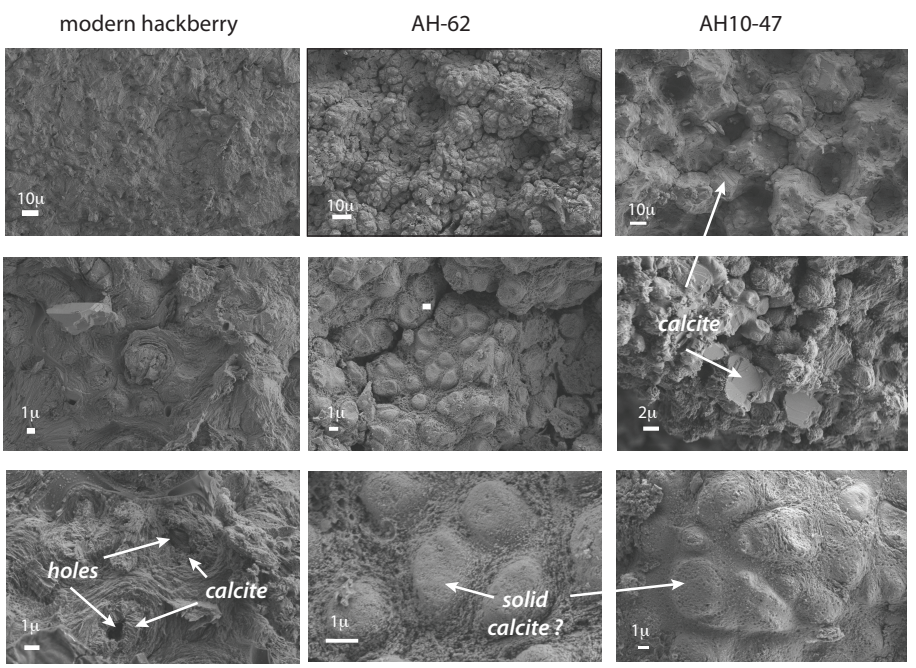

Figure 6. This figure compares modern (left) with archaeological (AH-62, center; AH10-47, right) hackberry endocarps at various levels of magnification under SEM. Carbonate minerals in both modern hackberry and archaeological endocarps are characterized by having a "honey-comb" texture (Wang et al. 1997). Each cell in the honey-comb consists of rounded calcite aggregates and surrounding fibrous aragonite. Open holes present in the modern sample become infilled with solid calcite in the archaeological samples AH-62 and AH10-47.

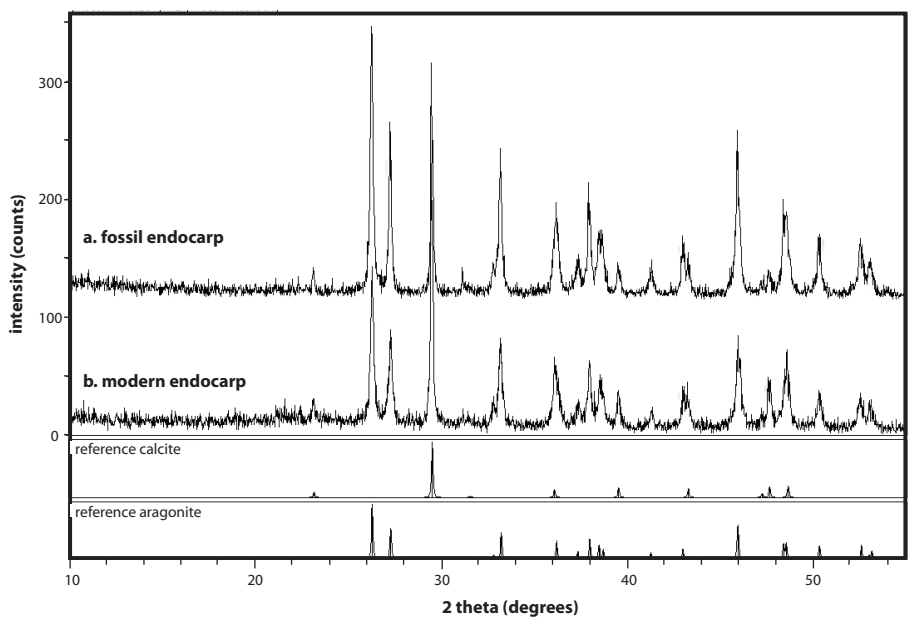

Figure 7. X-ray diffraction results reveal that the presence of aragonite and calcite minerals in endocarp of (a) fossil (AH10-47) and (b) modern hackberries. Previous studies only identify aragonite in modern endocarps. XRD traces for pure aragonite and calcite are shown for reference below.

\section{Perspective from Other Studies}

The $130-{ }^{14} \mathrm{C}$-year offset has not been described explicitly in any previous literature, perhaps because the offset is small and just above typical analytical errors of 50-100 years, and because the opportunity for fine-scale parallel sampling of charcoal and hackberries presented by the Asıklı Höyük case study is very unusual. In other studies (e.g. Wang et al. 1997; Pustovoytov and Riehl 2006), the archaeological sampling was not done by the geochronologists themselves; thus, it is not clear exactly how close the sampling associations are stratigraphically.
Nonetheless, other hackberry data sets do show some indication of anomalously young ages. Wang et al. (1997) found that in many cases ${ }^{14} \mathrm{C}$ dates from 8-35 ka endocarps were younger than that of co-occurring organic matter. However, they attributed the offset to layer mixing or contamination of the organic matter, not to problems with the carbonate dates. Their hackberry endocarps appeared well preserved, and free of detectable $(<1 \%)$ contaminating secondary calcite. Pustavoytov and Riehl (2006) also observed burnt seed ages greater than biogenic carbonate ages in two out of seven cases from Lithospermum, another plant that produces carbonate-bearing fruits.
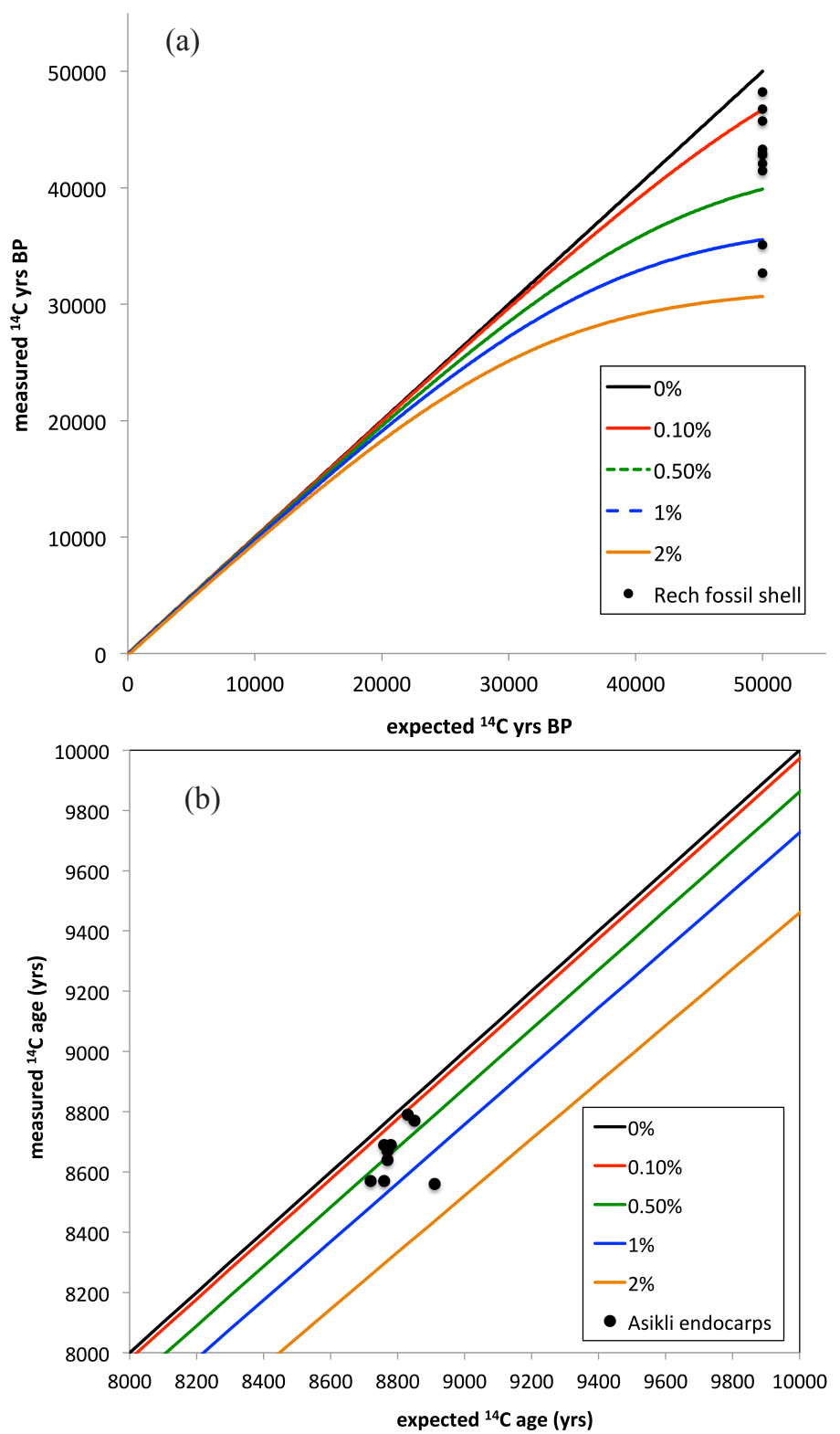

Figure 8. The effects on ${ }^{14} \mathrm{C}$ ages of variable (shown by lines 0.1 to $2 \%$ ) modern contamination, compared to (a) fossil ( $\geq 50 \mathrm{ka}$ ) shell reported on by Rech et al. (2011), and to (b) hackberry endocarps from Asıklı. Carbonate from both fossil shell and hackberries display subtle but measurable $0.1-2 \%$ contamination by modern carbon. 
An offset of 130 years in 10-ka samples is the equivalent of $\sim 0.5 \%$ contamination by modern carbon (Figure $8 \mathrm{~b}$ ). This level should be much more visible in old samples, where the effects of contamination are magnified by diminishing radiogenic ${ }^{14} \mathrm{C}$ content: $0.5 \%$ contamination of $\mathrm{a} \geq 50 \mathrm{ka}$ sample would produce an age of ca. $40 \mathrm{ka}$ (Figure 8a). We are not aware of any dating of such old endocarps. However, other very old fine-grained carbonate, such as shell aragonite, has been dated and it appears to experience the same subtle but measurable contamination, especially visible in older samples. Fossil shells studied by Rech et al. (2011) of infinite ${ }^{14} \mathrm{C}$ age ( $>50 \mathrm{ka}$ ) returned ages of 35-48 ka (Figure $8 \mathrm{a}$ ), which is consistent with 0.05 to $1.7 \%$ modern contamination. This overlaps the range of contamination of 0.1 to $1.5 \%$ contamination modern carbon from endocarps at Asıklı (Figure 8b). As in our study, Rech et al. (2011) demonstrated through SEM analysis the same subtle introduction of secondary calcite, in the case of shell as calcite overcoats onto primary aragonite.

\section{Implications for Dating of Endocarps}

Our work also demonstrates that although offset, dates obtained on Celtis may be sufficient for the needs of many archaeologists working on sites $<10,000$ years in age where other reliable sources of anthropogenic carbon are absent. Before dating, however, the context and state preservation of the endocarps should be evaluated. The minor contamination of aragonite by calcite was only detected in this study using XRD. FTIR analyses of hackberry endocarps from midden contexts indicate aragonitic compositions. Similarly, Shillito et al. (2009: Figure 7) analyzed samples from Çatalhöyük using FTIR and reported peak positions consistent only with aragonite. The results of our work suggest that although prescreening potential dating or isotopic samples using FTIR is appropriate for eliminating phosphatized or strongly recrystallized endocarps, a mineralogical analysis such as XRD should be conducted on each sample prior to further measurements.

\section{Stable Isotopic Composition}

In the Asıklı Höyük area, $\delta^{18} \mathrm{O}$ values of local meteoric waters range from -7.7 to $-10.6 \%$, and $\delta \mathrm{D}$ values from -64 to $-74 \%$ o (Figure 1; Table 2). The lowest values come from upland locations at elevations above $1500 \mathrm{~m}$, or from lowland stream and tap water apparently fed by these upland sources. Local spring water dripping from the Kizilkaya ignimbrite locally returned the highest isotopic values of $-7.7 \%$ and $-64 \%$ (Table 2, DGT10-4).

The hackberry endocarps yield unusually high $\delta^{18} \mathrm{O}$ (PDB) values, mostly $>0 \%$ (Table 3; Figure 9 ). We can contextualize our oxygen isotopic results by comparing them to a comprehensive data set of modern hackberry endocarps from North America assembled by Jahren et al. (2001). The $\delta^{18} \mathrm{O}$ values of North American endocarps are strongly correlated with the $\delta^{18} \mathrm{O}$ value of local meteoric water, and follow the relationship (recast from Jahren et al. 2001):

$\delta^{18} \mathrm{O}(\mathrm{PDB})_{\text {endocarp }}=0.67 \delta^{18} \mathrm{O}(\mathrm{SMOW})_{\text {meteoric water }}+7.42(\mathrm{r}=0.88) \quad[1]$

This translates into a roughly $+38 \%$ enrichment in endocarp aragonite compared to local source water (i.e. soil water).

In Figure 9, we calculated the $\delta^{18} \mathrm{O}$ value of endocarp aragonite predicted by Equation 1 using local Asıklı Höyük waters compared to actual $\delta^{18} \mathrm{O}$ values of modern and fossil endocarps. The underlying assumption here is that the $\delta^{18} \mathrm{O}$ values of local water have not changed appreciably over the last 10,000 years. We find that the $\delta^{18} \mathrm{O}$ values of most fossil endocarps lie between the field defined by predicted $\delta^{18} \mathrm{O}$ values and that of the modern shrubs (Figure 9). This suggests that most fossil plants harvested for their hackberries at Aşıklı are drawing on evaporated soil water, rather than the local (perched and regional) water table sampled in our study. These plants grow in the dry, bare soil areas resting on volcanic rocks topographically above the well-watered, incised watercourses.

Table 2. Isotopic composition of water in the Aşıklı area.

\begin{tabular}{llllllll}
\hline & $\delta^{18} \mathrm{O}$ & $\delta \mathrm{D}$ & \multicolumn{3}{l}{ Elevation } \\
Sample no. & $(\mathrm{SMOW})$ & $(\mathrm{SMOW})$ & ${ }^{\circ} \mathrm{N}$ & ${ }^{\circ} \mathrm{E}$ & (m asl) & Type & Area \\
\hline DGT10-4 & -7.7 & -64 & 38.34108 & 34.23806 & 1121 & spring & local seep in ignimbrite \\
DGT10-13 & -9.8 & -72 & 38.33399 & 34.23616 & 1131 & creek & Melendiz River at Aş1klı \\
DGT10-36a & -10.4 & -71 & $\mathrm{NA}$ & $\mathrm{NA}$ & 1378 & local tap & Helvedere - public tap \\
DGT10-38b & -10.5 & -71 & 38.16317 & 34.18647 & 1799 & local tap & Hasan Daği suction pump \\
DGT10-45 & -9.0 & -70 & 38.32559 & 34.23826 & 1137 & local tap & public tap Melendiz River \\
DGT10-50a & -10.4 & -75 & 38.28327 & 34.36150 & 1440 & local tap & near Güzelyurt \\
DGT10-51e & -10.6 & -74 & 38.26004 & 34.41347 & 1784 & local tap & east of Güzelyurt \\
DGT10-49a & -7.9 & -63 & 38.40454 & 34.29044 & 1174 & spring & spring in travertine quarry \\
DGT10-54a & -9.7 & -73 & 38.29139 & 34.21300 & 1287 & local tap & village of Usunkaya \\
DGT10-59a & -10.4 & -74 & NA & NA & 1527 & local tap & Gösterli \\
\hline
\end{tabular}

*All waters collected in July of 2010 or 2012. 
Table 3. Stable carbon isotope results from hackberry endocarps at Asıklı Höyük.

\begin{tabular}{|c|c|c|c|}
\hline Sample no. & $\begin{array}{l}\delta^{13} \mathrm{C} \\
(\mathrm{PDB})\end{array}$ & $\begin{array}{l}\delta^{18} \mathrm{O} \\
(\mathrm{PDB})\end{array}$ & Sample type \\
\hline AH-mod-2 & -11.0 & +13.9 & Celtis endocarp (modern) \\
\hline AH mod-3 & -11.0 & +13.3 & Celtis endocarp (modern) \\
\hline AH'09-56-1a & -9.8 & +5.5 & Celtis endocarp (archaeological) \\
\hline AH'09-56-1b & -9.5 & +6.7 & Celtis endocarp (archaeological) \\
\hline AH'09-56-1c & -9.7 & +6.3 & Celtis endocarp (archaeological) \\
\hline AH'09-56-1d & -9.6 & +6.6 & Celtis endocarp (archaeological) \\
\hline AH'09-56-1e & -10.6 & +3.6 & Celtis endocarp (archaeological) \\
\hline AH'09-56-2 & -10.0 & +9.1 & Celtis endocarp (archaeological) \\
\hline AH'09-56-3 & -10.2 & +7.9 & Celtis endocarp (archaeological) \\
\hline AH'09-56-4 & -9.5 & +5.7 & Celtis endocarp (archaeological) \\
\hline AH'09-56-5 & -12.1 & +7.1 & Celtis endocarp (archaeological) \\
\hline AH'09-58-1a & -9.7 & +8.9 & Celtis endocarp (archaeological) \\
\hline AH'09-58-1b & -10.2 & +9.2 & Celtis endocarp (archaeological) \\
\hline AH'09-58-2 & -8.2 & +9.9 & Celtis endocarp (archaeological) \\
\hline AH'09-58-3 & -9.4 & +13.9 & Celtis endocarp (archaeological) \\
\hline AH'09-58-4 & -8.7 & +12.9 & Celtis endocarp (archaeological) \\
\hline AH'09-58-5 & -10.3 & +10.0 & Celtis endocarp (archaeological) \\
\hline AH'09-60-1a & -8.5 & +6.5 & Celtis endocarp (archaeological) \\
\hline AH'09-60-1b & -8.5 & +6.3 & Celtis endocarp (archaeological) \\
\hline AH'09-60-2 & -10.7 & +6.8 & Celtis endocarp (archaeological) \\
\hline AH’09-60-3 & -8.1 & +5.1 & Celtis endocarp (archaeological) \\
\hline AH'09-60-4 & -10.7 & +8.2 & Celtis endocarp (archaeological) \\
\hline AH'09-60-5 & -9.9 & +9.2 & Celtis endocarp (archaeological) \\
\hline AH'09-62-1a & -6.5 & +7.1 & Celtis endocarp (archaeological) \\
\hline AH'09-62-1b & -6.6 & +6.9 & Celtis endocarp (archaeological) \\
\hline AH'09-62-1c & -6.5 & +6.7 & Celtis endocarp (archaeological) \\
\hline AH'09-62-1d & -6.6 & +5.5 & Celtis endocarp (archaeological) \\
\hline AH'09-62-1e & -6.6 & +6.8 & Celtis endocarp (archaeological) \\
\hline AH'09-62-2 & -10.3 & +9.3 & Celtis endocarp (archaeological) \\
\hline AH'09-62-3 & -9.5 & +7.5 & Celtis endocarp (archaeological) \\
\hline AH'09-62-4 & -9.8 & +6.8 & Celtis endocarp (archaeological) \\
\hline AH’09-62-5 & -9.2 & +5.6 & Celtis endocarp (archaeological) \\
\hline AH’09-64-1a & -7.3 & -4.1 & Celtis endocarp (archaeological) \\
\hline AH'09-64-1b & -7.9 & -2.1 & Celtis endocarp (archaeological) \\
\hline AH'09-64-1c & -7.5 & -4.0 & Celtis endocarp (archaeological) \\
\hline AH'09-64-1d & -7.3 & -3.7 & Celtis endocarp (archaeological) \\
\hline
\end{tabular}

*Archaeological site located at $38.34974^{\circ} \mathrm{N} ; 34.22954^{\circ} \mathrm{E} ; 1108 \mathrm{~m}$.

See Table 1 for ${ }^{14} \mathrm{C}$ dates from these samples and stratigraphic context.

An interesting exception is represented by four endocarps, samples AH-64a-d in Table 3. These yielded significantly lower values than predicted from local meteoric water values (Figure 9),

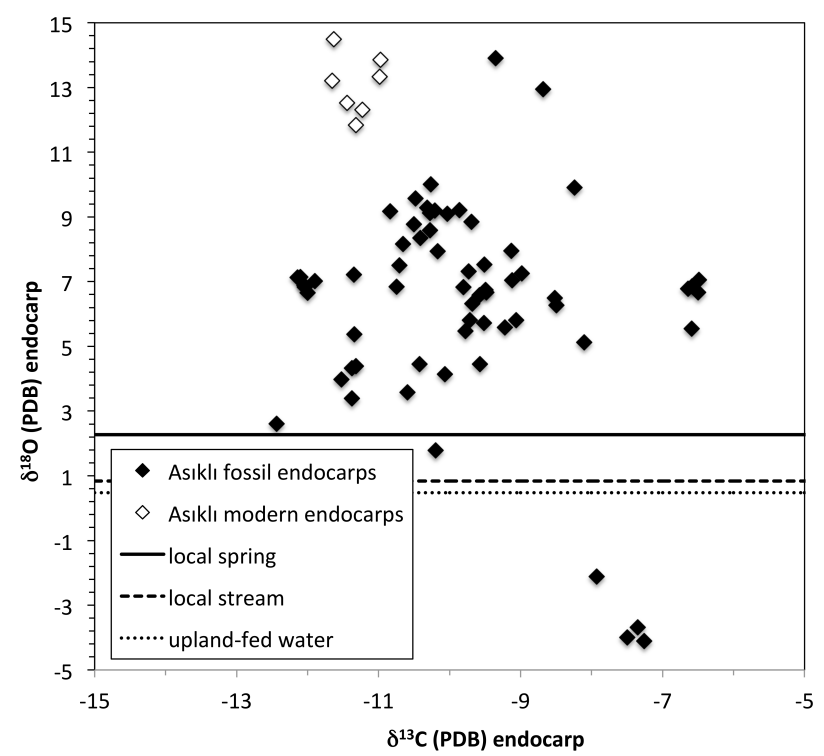

Figure 9. $\delta^{18} \mathrm{O}(\mathrm{PDB})$ versus $\delta^{13} \mathrm{C}(\mathrm{PDB})$ values of both modern and fossil hackberry endocarps. We compare these analyses to that of endocarps predicted to form from a range of local meteoric waters (horizontal lines) using the endocarp-water relationship for North American hackberries described in Jahren et al. (2001) (see text).

and therefore must have been imported from outside the region (to the north and/or at a higher elevation). This analysis assumes, of course, that the isotopic relationships observed for modern endocarps and water in North America holds for Cappadocia. A rigorous test awaits careful sampling all around the Asıklı Höyük area, taking in modern plant endocarps from a variety of landscape positions and elevations.

\section{ACKNOWLEDGMENTS}

The authors thank D. Dettman and A. Copeland for providing access to instrumentation and assisting with sample preparation or analysis, C. Pustovoytov and an anonymous reviewer for very helpful comments, and J. Rech for suggesting SEM analysis. The authors would also like to acknowledge the Turkish Ministry of Culture and Tourism, and the General Directorate of Cultural Assets and Museums for providing excavation and sample export permissions. Finally, the work at Asıklı Höyük has been generously supported by the Istanbul University Research Fund (Project numbers: 6647, 15794, 24030), and a National Science Foundation Grant (\# BCS-0912148) to M. Stiner.

\section{REFERENCES}

Buitenhuis, H., 1997. Aşıklı Höyük: A “protodomestication” site. Anthropozoologica 25-26:655-662.

Cowan, M. R., M. L. Gabel, A. H. Jahren, and T. L. Tiezsen, 1997. Growth and biomineralization of Celtis occidentalis (Ulmaceae) pericarps. American Midland Naturalist 137(2):266-273.

Esin, U., E. Bıçakçı, M. Özbaşaran, N. Balkan-Atlı, D. Berker, İ. Yağmur, and K. A. Atl1, 1991. Salvage excavations at the pre-pottery site of Aşıklı Höyük in Central Anatolia. Anatolica 17:123-174. 
Esin, U., and S. Harmankaya, 1999. Aşıklı. In Neolithic in Turkey, The Cradle of Civilisation, New Discoveries, 2 Volumes, edited by M. Özdoğan and N. Başgelen; pp. 115-132. Arkeoloji ve Sanat Yalınarı, Istanbul.

Goldberg, P., and F. Berna, 2010. Micromorphology and context. Quaternary International 214(1):56-62.

Jahren, A. H., R. Amundson, C. Kendall, and P. Wigand, 2001. Paleoclimatic reconstruction using the correlation in $\delta^{18} \mathrm{O}$ of hackberry carbonate and environmental water, North America. Quaternary Research 56(2):252-263.

Levin, I., and B. Kromer, 2004. The tropospheric ${ }^{14} \mathrm{CO}_{2}$ level in the mid-latitudes of the Northern Hemisphere. Radiocarbon 46(3):1261-1272.

Matthews, W., 2005. Micromorphological and microstratigraphic traces of uses and concepts of space. In Inhabiting Catalhoyuk: Reports from the 1995-99 Seasons, Volume 4, edited by I. Hodder; pp. 355-398. McDonald Institute for Archaeological Research, Cambridge.

Özbaşaran, M., and H. Buitenhius, 2002. Proposal for a regional terminology for central Anatolia. In The Neolithic of Central Anatolia, Internal Developments and External Relations during the 9th-6th Millennia cal. BC, edited by F. Gerard and L. Thissen; pp. 67-77. Ege Yayınları, Istanbul.

Pustovoytov, K., and S. Riehl, 2006. Suitability of biogenic carbonate of Lithospermum fruits for ${ }^{14} \mathrm{C}$ dating. Quaternary Research 65(3):508-518.

Pustovoytov, K., S. Riehl, H. H. Hilger, and E. Schumacher, 2010. Oxygen isotopic composition of fruit carbonate in Lithospermeae and its potential for paleoclimate research in the Mediterranean. Global and Planetary Change 71(3):258-268.

Rech, J., J. Pigati, S. B. Lehman, C. N. McGimpsey, D. A. Grimely, and J. C. Nekola, 2011. Assessing open-system behavior of ${ }^{14} \mathrm{C}$ in terrestrial gastropod shells. Radiocarbon 53(2):325-335.

Shillito, L. M., M. J. Almond, J. Nicholson, M. Pantos, and W. Matthews, 2009. Rapid characterisation of archaeological midden components using FT-IR spectroscopy, SEM-EDX and micro-XRD. Spectrochimica Acta Part A: Molecular and Biomolecular Spectroscopy 73(1):133-139.

Stiner, M. C., H. Buitenhuis, G. Duru, S. L. Kuhn, S. M. Mentzer, N. Munro, N. Pöllath, J. Quade, G. Tsartsidou, and M. Özbasaran, 2014. A forager-herder trade-off, from broad-spectrum hunting to sheep management at Așıklı Höyük, Turkey. Proceedings of the National Academy of Sciences 111(23):8404-8409.

Stoops, G., 2003. Guidelines for Analysis and Description of Soil and Regolith Thin Sections. Soil Science Society of America, Madison, WI.

Toffolo, M. B., A. M. Maeir, J. R. Chadwick, and E. Boaretto, 2012. Characterization of contexts for radiocarbon dating: Results from the early Iron Age at Tell es-Safi/Gath, Israel. Radiocarbon 54(3-4):371-390.

Tucker, M., 1995. Techniques in Sedimentology. Blackwell Science, London.

Wang, Y., H. Jahren, and R. Amundson, 1997. Potential for ${ }^{14} \mathrm{C}$ dating of biogenic carbonate in hackberry (Celtis) endocarps. Quaternary Research 47(3):337343 . 